\title{
O Ensino Religioso no debate atual: trajetórias, conceitos e propostas
}

\author{
Religious Education in the current debate: trajectories, \\ concepts and proposals
}

\author{
Daniele Ventura ${ }^{1}$ \\ Maria José Holmes²
}

\section{Resumo}

O presente trabalho tem como objetivo subsidiar as discussões atuais sobre o Ensino Religioso, a partir de um debate conceitual e histórico. Compreendendo o fenômeno religioso como um conceito basilar a ser introduzido em sala de aula, apresentaremos aqui algumas de suas definições para enfatizar as semelhanças existentes em cada religião e como todas elas precisam estar presentes em sala de aula, mediante a pluralidade religiosa brasileira. Complementando esta discussão, observaremos ainda o significado da diversidade religiosa, para que se evidencie o Ensino Religioso como lugar de respeito às diferenças, a partir das discussões presentes no Fórum Nacional Permanente do Ensino Religioso- FONAPER e em autores da área de educação e religião. Não deixaremos de ressaltar, ainda, como este componente curricular vem sendo internalizado no aparato legal brasileiro ao longo dos anos, apresentando inclusive à última solicitação do Supremo Tribunal Federal por um Ensino Religioso confessional, para que se tornem perceptíveis as contradições, convergências e divergências deste debate. Metodologicamente, esse artigo se pauta em uma análise documental e bibliográfica no momento em que se utiliza de fontes como os Parâmetros Curriculares Nacionais do Ensino Religioso (PCNER), a Constituição Federal de 1988, a Lei 9394/1996, da Lei 9475/97 e da própria Base Nacional Comum Curricular - BNCC, em diálogo com autores da área de educação e religião. Como resultados, podemos apontar que o Ensino Religioso, ao ser considerado como componente curricular que se pauta no fenômeno religioso e no respeito à diversidade religiosa, dá ao leitor uma noção de sua importância em sala de aula e permite que se tornem explícitos os equívocos referentes à compreensão deste componente curricular, que se contrapõe ao proselitismo e ao desrespeito a qualquer religião. A abordagem histórica por

\footnotetext{
${ }^{1}$ Vice-coordenadora do grupo de pesquisa FIDELID, Professora substituta do Departamento de Ciências das Religiões, Graduada em História e Mestre em Ciências das Religiões pela UFPB, Doutora em Ciências da Religião pela PUC-GO.

2 Pedagoga- Prof ${ }^{\mathrm{a}}$. Ensino Religioso. Especialista e Mestra em Ciências das Religiões UFPB. Membro do Conselho Fiscal do FONAPER. Grupo de Pesquisa: FIDELID.
} 
sua vez é esclarecedora de que, apesar de termos, no passado, uma ênfase ao ensino do cristianismo na Escola, nos contrapomos consideravelmente a este modelo educacional, primando pelo respeito à diversidade religiosa.

Palavras-Chave: Fenômeno Religioso. Diversidade. Ensino Religioso. BNCC.

\section{Abstract}

The present work aims to support the current discussions about Religious Education, based on a conceptual and historical debate. Understanding the religious phenomenon as a basic concept to be introduced into the classroom, we present here some of its definitions to emphasize the similarities that exist in each religion and how they all need to be present in the classroom Through the Brazilian religious plurality. Complementing this discussion, we will also observe the significance of religious diversity in order to demonstrate religious teaching as a place of respect for differences from the discussions present in then Permanent National Forum of Religious Educationand in authors of the area of education and religion. We will not fail to emphasize how this curricular component has been introduced in the Brazilian legal apparatus over the years, emphasizing the last request of the majority of the Supreme Federal Court for a Confessional Religious Education so that the contradictions, convergences and divergences of this debate become perceptible. Methodologically, this article is based on a documentary and bibliographical analysis when using sources such as National Curricular Parameters of Religious Education, CF / 88, LDB / 96 and Law 9475/97 and the Common National Base Curriculum (CNBC) itself in dialogue with authors from the field of education and religion. As a result, we can point out that Religious Education, when considered as a curricular component that is based on religious phenomena and respect for religious diversity, gives the reader a sense of its importance in the classroom and allows the misunderstandings regarding understanding of this curricular component that opposes proselytizing and disrespect to any religion. The historical approach in turn is illuminating that, although we have in the past an emphasis on the teaching of Christianity in the School, we are considerably opposed to this educational model, with respect for religious diversity.

Keywords: Diversity, Religious Teaching, Religious Phenomenon, CNBC

\section{Introdução}


Religare, ISSN: 19826605, v.15, n.1, agosto de 2018, p.48-74.

Este artigo é fruto de muitas pesquisas realizadas na área da(s) Ciência(s) da(s) Religião(ões) ao longo dessa caminhada relacionada ao Ensino Religioso (ER), considerando a diversidade cultural religiosa existente no Brasil, enquanto um país laico.

O objetivo deste trabalho é subsidiar as discussões atuais sobre o Ensino Religioso ${ }^{3}$, a partir de definições sobre o fenômeno religioso e o respeito à diversidade e de uma abordagem histórica sobre como este componente curricular vem sendo introduzido no aparato legal brasileiro, ao longo dos anos.

Metodologicamente, faremos uma análise documental das legislações, Constituições e também dos Parâmetros Curriculares Nacionais do Ensino Religioso, em diálogo com autores da sociologia, da fenomenologia da religião e da educação.

A princípio, serão apresentadas definições para o fenômeno religioso, visto que são essas noções que precisam estar presentes nas discussões em sala de aula, a fim de que discentes e docentes saibam os pontos em comum, presentes nas tradições religiosas que as configuram como tais.

Após trazermos tais definições, observaremos ainda a diversidade cultural na construção pedagógica do Ensino Religioso, pois, a partir daí, daremos ao leitor a oportunidade de conhecer a proposta das Ciências das Religiões e do Fórum Nacional Permanente do Ensino Religioso - FONAPER ${ }^{4}$

\footnotetext{
${ }^{3}$ Destaca-se aqui, especialmente, as produções atuais do GPER - Grupo de Pesquisa do Educação e Religião Formação docente e Educação Religiosa coordenado pelo professor Sérgio Junqueira e as seguintes obras: Compêndio do Ensino Religioso (2017); Socialização do saber e produção científica do ensino religioso (2017) e o Ensino Religioso no Brasil (2011)

${ }^{4}$ O Fórum Nacional Permanente do Ensino Religioso é uma associação civil de direito privado, de âmbito nacional, sem vínculo político-partidário, confessional e sindical, sem fins econômicos, que congrega, conforme seu estatuto, pessoas jurídicas e pessoas naturais identificadas com o Ensino Religioso, sem discriminação de qualquer natureza. Fundado em 26 de setembro 1995, em -Florianópolis/SC, vem atuando na perspectiva de acompanhar, organizar e subsidiar o esforço deprofessores, pesquisadores, sistemas de ensino e associações na efetivação do Ensino Religioso como componente curricular. Esse fórum contém o Estatuto que rege as normas, direitos e deveres de seus associados, a Carta de Princípios, que contém o contrato moral que todo associado desse Fórum estabelece consigo mesmo e com a Educação e o Contrato que se projeta
} 
Religare, ISSN: 19826605, v.15, n.1, agosto de 2018, p.48-74.

para este componente curricular. Essa análise se faz necessária, pois, a partir dela, poderemos desconstruir algumas compreensões distorcidas sobre a presença do Ensino Religioso em sala de aula em um país laico.

Por fim, faremos uma abordagem histórica sobre a presença deste componente curricular no Brasil, mencionando as legislações, a Constituição e a atual Base Nacional Comum Curricular (BNCC), que ao ser discutida pelo Supremo Tribunal Federal - STF, teve como peculiaridade o fato de muitos deles, de forma conservadora, defenderem um Ensino Religioso de cunho confessional, contrariando várias discussões abordadas pelo FONAPER e por profissionais da área.

\section{O Fenômeno Religioso em discussão: conceitos introdutórios para a Sala de Aula}

Ao focarmos no fenômeno religioso, se faz necessário conceituá-lo, para que seja melhor compreendido, tanto no aspecto das ciências humanas, quanto na origem das religiões. A religião é considerada como um fenômeno humano, não só individual, mas em grupo e em sociedade. Almeida (2000) apresenta três exemplos de conceito sobre o fenômeno religioso, quando afirma que:

1- O fenômeno religioso é um verdadeiro fenômeno humano, que se traduz por atitudes e costumes característicos, nos quais podemos observar tanto o "acontecimento" religioso quanto a sua significação religiosa; basta considerar a sua manifestação mais típica, a "oração"; 2- O fenômeno religioso

\footnotetext{
para além de compromissos jurídicos e institucionais. Seus documentos são: 1- Parâmetros Curriculares Nacionais do Ensino Religioso- PCNER; 2- Caderno temático no 1 Ensino Religioso: Referencial curricular para a proposta pedagógica da escola; 3- Caderno temático $\mathrm{n}^{\mathrm{o}}$ 2- Ensino Religioso: Culturas e tradições religiosas; 4- Caderno Temático № 3 Ensino Religioso: Capacitação para um novo milênio; 5- Propostas de Diretrizes Curriculares Nacionais para o Curso de Graduação em Ciências da Religião - Licenciatura em Ensino religioso; 6-Concepção de Ensino Religioso no FONAPER: Trajetórias de $51 \mathrm{~m}$ conceito em construção. Essas informações estão disponíveis no site oficial do FONAPER: $<w w w$.fonaper.com.br>
} 
Religare, ISSN: 19826605, v.15, n.1, agosto de 2018, p.48-74.

radica-se na própria natureza humana, pelo que é possível, neste princípio de unidade, chegar a sua própria essência;

3- O fenômeno religioso é decisivo para o comportamento humano e para a estruturação da sociedade e, por isso, deve ter um "significado" próprio e profundo. (ALMEIDA, 2000, p.9)

Apesar da complexidade desse tema, observa-se que o encontro com o sagrado remete ao ser humano uma dimensão transcendental. O plano das relações simbólicas que desafiam este "ser" a aprofundar sua humanidade se dá através de toda uma rede de símbolos que permeiam não só a religião, como também a linguagem, a arte e todos os valores. Isso vem facilitar e, concomitantemente, contribuir para o crescimento da pessoa, bem como para "o cuidar do ser humano" permanentemente, assim esse "ser" poderá aprender "a cuidar de si" e "a cuidar do outro", respeitando às diferenças.

Ao abordarmos sobre o fenômeno religioso, observamos o fato de sua complexidade ser tão profunda e inexplicável, não só para pesquisadores, mas principalmente para o leitor. Portanto, se faz necessário entender o seu significado. Segundo Holmes (2010):

Desde os primórdios da vida no mundo e tudo que há nele é que os pesquisadores cientistas procuram investigar sobre o fenômeno religioso ${ }^{5}$, para saber o porquê da sua existência, se há algo mais do que aquilo que já se conhece. As ciências humanas estão sempre pesquisando sobre os mais variados sistemas religiosos, porém, a religião se mostra aos olhos dos cientistas com suas diferenças e estes mergulham em suas pesquisas, para compreendê-las melhor e aprofundar os seus conhecimentos sobre o fenômeno religioso e como cada sistema religioso se comporta diante de tal fenômeno. (HOLMES, 2010, p.24)

Para a autora supracitada, Durkheim, quando optou pelo estudo de uma religião primitiva, estaria conhecendo o universo religioso das outras religiões. (HOLMES, 2010, p. 99) Nesta perspectiva, considera-se que as

\footnotetext{
${ }^{5}$ De modo simples podemos dizer que é um acontecimento em que se manifesta a religiosidade coletiva ou individual, motivado pela fé ou pela crença. Isso pode ocorrer nas diferentes correntes religiosas independentes do lugar e do tempo. (STEEL, 2009, p. 17) 
Religare, ISSN: 19826605, v.15, n.1, agosto de 2018, p.48-74.

crenças primitivas tiveram sua origem na religião. Durkheim, ao se referir às religiões, afirma que:

[...] Todas são igualmente religiões, como todos os seres vivos são igualmente vivos, desde os mais simples plastídios até o homem. Portanto, se nos voltarmos para as religiões primitivas não é com a intenção de depreciar a religião em geral; porque essas religiões primitivas não são menos respeitáveis que as outras. Elas respondem às mesmas necessidades, desempenham o mesmo papel, dependem das mesmas causas; portanto podem perfeitamente servir para manifestar a natureza da vida religiosa e, por conseguinte, para resolver o problema que desejamos tratar. (DURKHEIM, 1989 , p.31).

Entende-se, portanto, que Durkheim (1989) não faz distinção entre esta ou aquela religião, demonstrando assim, em suas pesquisas, que embora existam diferenças entre as religiões, em um aspecto elas são iguais, ou seja, em serem consideradas como tais, todas com suas verdades. Eis aí a causa desse autor ter escolhido uma religião primitiva para ser o seu objeto de estudo.

Oro (2013), em sua fala sobre as ciências sociais, explica que essa ciência estuda a religião enquanto linguagem, distanciando-se da ideia de fé ou divino. Para ele, o fenômeno religioso dá lugar a um fato social e, por isso, assegura que:

Ao olhar das ciências sociais, pode-se dizer que o estudioso, ao se aproximar do e analisar o fenômeno religioso, percebe que as coisas, os elementos e expressões religiosas não são todas iguais. Como cientista, contudo jamais pode emitir um juízo afirmando que existem religiões mais verdadeiras e menos verdadeiras. Um sociólogo faz sociologia, não uma sociologia católica nem sociologia umbandista, nem sociologia protestante. (ORO, 2013, p. 17)

Quanto mais investigamos o fenômeno religioso, há de se convir, que adentramos em um mundo de mistérios para descobrir o sentido mais profundo da vida e da morte, bem como procuramos por isso, não apenas no presente, mas no passado e também no real e no imaginário. Por mais que 
Religare, ISSN: 19826605, v.15, n.1, agosto de 2018, p.48-74.

recuemos, pode-se constatar indícios de cultos religiosos entre os nossos antepassados, a partir de toda uma simbologia e de ritos inerentes às tradições religiosas. Esse autor assegura ainda que: “Nossa sociedade e, talvez, nossas casas estão cheias de símbolos religiosos. São símbolos que fazem parte da religiosidade popular. Se estão aí é porque dizem alguma coisa para as pessoas. Fazem sentido." (ORO, 2013 p. 18). Diante das afirmações desses autores, observa-se que não há distinção entre as religiões, todas desempenham a sua função de forma similar.

Todavia, percebemos que esse fenômeno religioso está presente em nossas vidas desde o nascimento até a morte. É comum entre as pessoas, em suas residências, compartilharem momentos espirituais no seu cotidiano, através de suas orações diárias, de súplicas e/ou de agradecimentos, fazerem suas oferendas junto ao Divino, seja qual for sua religião. Outras procuram a natureza, com o intuito de se conectarem com o Sagrado e há também aqueles que não professam uma religião e os que são ateus. Sobre isso, é relevante destacar aquilo que Hervieu-Leger (2008) denomina de fé peregrina ou bricolagem da fé, presente neste contexto secularizado, e opondo-se à figura do convertido, presente nas práticas religiosas de cunho fundamentalista. De uma forma geral, existem momentos de reflexão da vida, que Berger (2004) denominou de situações-limite e de estado de anomia, em que uma pessoa procura lugares onde possa se recolher e se encontrar consigo mesma. Ao utilizar o conceito de hierofania para os lugares sacralizados, Eliade (1993, p. 9) observa que:

O fato de uma hierofania ser sempre histórica (isto é, de se produzir sempre em situações determinadas) não destrói necessariamente a sua ecumenicidade. Algumas hierofanias têm um destino local; há outras que têm, ou adquirem valores universais. Os indianos, por exemplo, veneram certa árvore chamada Açvattha; simplesmente para eles a manifestação do sagrado nesta espécie vegetal é transparente, pois só para eles a Açvattha é uma hierofania e não apenas uma árvore. (ELIADE, 1993, p. 9) 
Religare, ISSN: 19826605, v.15, n.1, agosto de 2018, p.48-74.

É nessa diversidade cultural-religiosa que percebemos as mais variadas formas de se relacionar com o Transcendente, quer seja nos escritos sagrados, quer seja na oralidade. Em qualquer lugar, observamos a forma de culto ao divino, não somente nos templos, casas de orações, terreiros ou centros e, até mesmo num lugar livre, escolhendo a própria natureza, seja em coletividade ou individual, contribuindo para uma abertura de caminhos, em que as pessoas buscam as respostas mais significativas para os seus questionamentos: a origem de tudo; o universo; a criação do mundo; a vida pós-morte e, por fim, como as religiões concebem o fenômeno religioso.

Ainda na visão de Eliade (2001 p.17): “O homem toma conhecimento do sagrado porque este se manifesta, se mostra como algo absolutamente diferente do profano". Essa experiência, para o ser humano, é algo que traduz momentos de sua relação com o Transcendente e que vai além da sua essência. $\mathrm{Na}$ vida daquele que crê, é comunicar-se espiritualmente, e com espontaneidade, junto ao Divino.

Sabemos que as Ciências Humanas nos levam à compreensão sobre o fenômeno religioso, através da dimensão do multiculturalismo e da transdisciplinaridade, considerando que este deve ser tratado na escola como conhecimento científico de um componente curricular, e como tal não pode ser negado aos estabelecimentos de ensino público, tendo em vista que este é o foco da diversidade cultural religiosa.

Na visão didático-pedagógica do Ensino Religioso, é relevante e necessário que docentes e discentes compreendam que o fenômeno religioso é o objeto de estudo deste componente curricular. Para isso, eles/elas precisam entender que a escola é um espaço onde se adquire conhecimentos e entre estes está o conhecimento religioso. Os Parâmetros Curriculares Nacionais do Ensino Religioso afirmam:

Como na sociedade democrática todos necessitam da Escola para ter acesso a parcela de conhecimento histórico 
Religare, ISSN: 19826605, v.15, n.1, agosto de 2018, p.48-74.

acumulado pela humanidade, através de conteúdos escolares, o conhecimento religioso enquanto patrimônio da humanidade necessita estar à disposição na Escola. É preciso, portanto, prover os educandos de oportunidades de se tornarem capazes de entender os momentos específicos das diversas culturas, cujo substrato religioso colabora no aprofundamento para a autêntica cidadania. (PCNER, 2009 p. 44-45)

Contudo, compreender sobre o conhecimento religioso requer do professor uma abertura para um diálogo entre docentes e discentes, para discutir e debater sobre a diversidade cultural religiosa, dando a liberdade de falar e ouvir, despertando no estudante uma visão de mundo, de maneira diversificada, de acordo com a forma como cada um entende a sociedade em que vive e as crenças nela existentes.

A escola, na construção do seu currículo, deve caracterizar o conhecimento, e nele o papel do Ensino Religioso, de forma criativa e dinâmica. Para isso, precisa considerar pelo menos quatro aspectos importantes: "1- Entender o conhecimento como um processo em construção; 2-Pensar a pessoa como totalidade; 3- Dialogar com a diversidade; 4Preservar a memória." (FONAPER, 2000, p. 9, Caderno 3).

Observamos que, nessa perspectiva, o Ensino Religioso, estudado e compreendido dessa maneira em sala de aula, oferece uma grande contribuição para o desenvolvimento dos discentes, pois é na escola que se apresenta um dos melhores espaços para o diálogo com a diversidade. $\mathrm{Na}$ Escola temos a oportunidade de construir conhecimentos, bem como de fazer história e logicamente desenvolver o crescimento do ser humano, a partir da percepção dos valores universais ${ }^{6}$, na perspectiva sociocultural e na promoção da cidadania.

\footnotetext{
6 Sobre isso, veja-se: Pinheiro (2016).
} 
Religare, ISSN: 19826605, v.15, n.1, agosto de 2018, p.48-74.

\section{Diversidade Cultural Religiosa na Construção Pedagógica do Ensino Religioso}

Ninguém nasce odiando outra pessoa pela cor de sua pele, por sua origem ou ainda por sua religião. Para odiar, as pessoas precisam aprender; e, se podem aprender a odiar, podem ser ensinadas a amar. (Nelson Mandela).

A proposta atual do Ensino Religioso trata do respeito à diversidade cultural religiosa, e nessa diversidade, o fenômeno religioso. Este componente curricular ainda é considerado por muitos "o patinho feio", esta é uma pequena expressão, usada com muita sensibilidade e sabedoria pela autora Anísia Figueiredo, porque, na concepção da sociedade, o ER é "aula de religião" e, na visão dessas pessoas, a religião deve ficar de fora da escola. Para elas, o ER quer se estabelecer na escola para evangelizar e/ou doutrinar, imbuídos pelos resquícios de um passado de cinco séculos motivados pela colonização de índios e negros, alavancados pelo domínio de uma só religião (Cristã). Isso nos faz refletir, ou não, sobre o que motivou a sua retirada da Base Nacional Comum Curricular. São comuns nas redes sociais as seguintes indagações: "Para que religião na escola?" "Eu já tenho a minha religião! Para que outra?" "Eu não acredito em Deus! Fora Ensino Religioso!"

Dessa mesma forma, refletiram os juízes do Supremo Tribunal Federal (STF) por ocasião do julgamento desse componente curricular, se seria ou não conservado na grade curricular das escolas (Ação Direta de Inconstitucionalidade - ADI - 4439) ${ }^{7}$ o que gerou forte polêmica na

\footnotetext{
7 A Ação Direta de Inconstitucionalidade (ADI) 4439) teve como Relator o ministro Luís Roberto Barroso, então Procurador-geral da República x Presidente da República e Congresso Nacional. Na ação, o procurador-geral requereu interpretação conforme a Constituição do artigo 33, caput e parágrafos $1^{\circ}$ e $2^{\circ}$, da Lei $n^{\circ}$ 9.394/96, para assentar que o Ensino Religioso em escolas públicas só pode ser de natureza não-confessional, ou seja, sem vinculação a uma religião específica, com proibição de admissão de professores na qualidade de representantes das confissões religiosas. Pediu ainda a interpretação, conforme a Constituição do artigo 11,
} 
Religare, ISSN: 19826605, v.15, n.1, agosto de 2018, p.48-74.

sociedade, pela permanência ou não do Ensino Religioso nas escolas públicas. De um lado os que queriam, respeitando a diversidade cultural religiosa do País, do outro os que queriam a confessionalidade. Além daqueles que queriam vê-lo distante da escola pública. Apenas em um aspecto os juízes se diferenciaram da população. Nesse julgamento, a maioria deles optou por um Ensino Religioso Confessional.

Mediante a laicidade do Estado Brasileiro, abre-se a discussão sobre a inviabilidade de se ensinar religião por não combinar com a escola pública. Nesse ponto de vista, concordamos, porque, ao contrário do que se pensa, realmente na escola não se ensina religião. Religião se ensina nos templos sagrados, nas comunidades de fé e na família. Enquanto que na escola se constrói conhecimentos, e entre estes está o estudo do fenômeno religioso, pois, além dessa laicidade, existe a pluralidade da escola de um modo geral e nela há a diversidade cultural religiosa. Acrescenta-se aqui ainda o direito de ter ou não religião e também o de crer ou não. Esta concepção precisa estar presente nas práticas escolares dos professores do Ensino Religioso para garantir o respeito às diferenças em sala de aula.

Diante desses impedimentos, é imprescindível que essa temática seja abordada em sala de aula, pois é fundamental que os estudantes compreendam o que é a diversidade religiosa, para que possam acolhê-la e

parágrafo 1ํㅡㄹ do acordo firmado entre o Brasil e a Santa Sé sobre o Estatuto Jurídico da Igreja Católica no Brasil, para assentar que o Ensino Religioso em escolas públicas apenas pode ser de natureza não-confessional ou, caso incabível, que seja declarada a inconstitucionalidade do trecho "católico e de outras confissões religiosas", constantes no artigo 11, parágrafo $1^{\mathfrak{0}}$, do acordo. Destaca, em síntese, que a "Constituição da República consagra a um só tempo, o princípio da laicidade do Estado (artigo 19, inciso I) e a previsão de que "o Ensino Religioso, de matrícula facultativa, constituirá disciplina dos horários normais das escolas públicas de ensino fundamental" (artigo 210, parágrafo $1^{\underline{0}}$ )". Dessa forma, concluiu-se que a única forma de compatibilizar o caráter laico do Estado brasileiro com o Ensino Religioso nas escolas públicas é -através da adoção do modelo não-confessional. Em 15 de junho de 2015 foi realizada audiênciapública para debater o tema. Está em discussão atualmente saber se é constitucional a interpretação dos dispositivos impugnados no sentido de que o ensino religioso nas escolas públicas somente poderá possuir natureza não-confessional. Pode acompanhar esta ação pelo site: <http://www.stf.jus.br/portal/cms/verNoticiaDetalhe.asp?idConteudo=353973> 
Religare, ISSN: 19826605, v.15, n.1, agosto de 2018, p.48-74.

respeitá-la, através da construção do conhecimento sobre o fenômeno religioso. Compreende-se, portanto, o Ensino Religioso como capaz de dar ao cidadão o sentido da vida, como se pode observar no que está estabelecido pelos PCNER (2009 p. 46): “O Ensino Religioso, valorizando o pluralismo e a diversidade cultural presente na sociedade brasileira, facilita a compreensão das formas que exprimem o Transcendente na superação da finitude humana e que determinam subjacentemente o processo histórico da humanidade".

Este pensar colabora com a reflexão sobre a sua importância para o verdadeiro sentido da vida, pois é a partir desse componente curricular que docentes e discentes, de forma dialógica, constroem esse conhecimento com eticidade, como se pode destacar em uma das finalidades do Ensino Religioso estabelecidas pela BNCC (2017, p. 434): “Contribuir para que os educandos construam seus sentidos pessoais de vida a partir de valores, princípios éticos e da cidadania."

Assim sendo, este componente curricular, ao ser incluído enquanto área do conhecimento, propicia ao educando se tornar sujeito da construção da sua própria história e da sociedade em que vive. Aplicado na educação enquanto um processo de desenvolvimento global, o Ensino Religioso facilita uma abertura para o diálogo entre docentes e discentes, facilitando, para estes, tudo o que é imprescindível em ensinar e aprender para vida de cada um/uma, sendo a escola um lugar ideal para isso, "dentro de uma visão de totalidade os vários níveis de conhecimento: o sensorial, o intuitivo, o afetivo, o racional e o religioso." (PCNER, 2009 p. 44).

Portanto, este é um processo de conhecimento global que faz parte da vida humana, numa perspectiva de crescimento individual e coletivo, assegurando a interação entre as pessoas e o meio em que vivem e convivem.

Freire (2007, p. 90) assegura que: “A existência, porque humana, não pode ser muda, silenciosa, nem tampouco pode nutrir-se de falsas palavras, mas de palavras verdadeiras, com que os homens transformam o mundo". 
Religare, ISSN: 19826605, v.15, n.1, agosto de 2018, p.48-74.

Esse autor se refere ainda sobre a importância e o significado do diálogo na vida do ser humano, para desmistificar preconceitos e promover o respeito:

O diálogo tem significação precisamente porque os sujeitos dialógicos não apenas conservam sua identidade, mas a defendem e assim crescem um com o outro [...]. Implica, ao contrário, um respeito fundamental dos sujeitos neles engajados, que o autoritarismo rompe ou não permite que se constitua. (FREIRE, 2007, p. 118)

Para que se compreenda que a intolerância provoca violência e desrespeito para com o sagrado do outro, é importante que essa discussão aconteça no ambiente escolar. Faz-se necessário, portanto, que o educador esteja atento quanto a isto, demonstrando para os estudantes o respeito à diversidade, sempre orientando para o convívio solidário. Pode-se demonstrar isso, sempre quando as oportunidades surgirem e levá-los, com exemplos, a refletirem e se colocarem no lugar do outro, antes de qualquer atitude preconceituosa e desrespeitosa. Trata-se, portanto, de uma busca incessante por um diálogo fundamentado no princípio da alteridade.

Segundo Oliveira et al. (2007, p.111): “É no exercício do diálogo com o diferente que o ser humano engendra a possibilidade de flagrar-se também como um diferente e um outro diante de alguém outro. Quando o eu e o outro se percebem, nasce a ética. [...]". Contudo, nem sempre essa compreensão para o Ensino Religioso existiu e a construção desta reflexão que ainda vigora na atualidade será discutida no próximo item.

\section{O Ensino Religioso do passado ao presente, A Legislação Brasileira e A BNCC}

Nestes cinco séculos de história do Ensino Religioso é comum que a sua apresentação seja realizada a partir de uma leitura que pode ser compreendida por diversos ângulos. Assim, afirma Oliveira: ${ }^{8}$

\footnotetext{
${ }^{8}$ OLIVEIRA, Lilian Blank de. Prefácio da obra: Ensino Religioso: Esperanças e Desafios reflexões da práxis do cotidiano escolar. HOLMES (2016).
} 
Religare, ISSN: 19826605, v.15, n.1, agosto de 2018, p.48-74.

As raízes do pensamento educacional europeu se fizeram presentes e foram determinantes durante longos períodos nestes mais de 500 anos. As contribuições dos mais de 300 povos originários desta terra foram aproveitadas e incorporadas na medida em que atendiam aos interesses da matriz política ideológica. Conquistas e atos de poder quando não as dizimaram, visaram mutilar suas entranhas para que seus suspiros não mais exalassem lições de sabedoria entretecidas com conhecimentos acerca do ser humano, educação e vida. [...]. Os povos africanos adentrando por imposição em território brasileiro trouxeram consigo mais e novas possibilidades de abertura de horizontes no campo econômico, cultural e religioso para a colônia portuguesa aqui radicada. Entretanto, seus múltiplos conhecimentos foram invisibilizados e reduzidos a mero trabalho braçal, sua sabedoria e religiosidade minimizada e transfigurada em atos de magia e ocultismo. (OLIVEIRA, 2016, p.16)

Essa foi uma página da história de Ensino Religioso que, durante esses longos anos, projetou-se a serviço de uma cultura religioso-cristã, que era imposta aos indígenas e aos negros através de um culto religioso distante de suas raízes culturais (CÂNDIDO, 2009). O projeto religioso dessa educação estava vinculado ao poder de reis e da aristocracia, cujo motivo religioso obedecia ao regime do padroado entre Igreja e Estado. É uma fase imperada nos moldes da religião cristã católica, em que se desenvolvia a evangelização e a catequese. Nessa época o ER era chamado de Instrução Religiosa. Alguns jesuítas até tentaram falar a língua Tupi, porém não foi aceita pelo governo português. Isto era resultado do pacto colonial, que proibia tudo que não era interesse da corte portuguesa, pois tudo estava voltado para o desenvolvimento econômico de um regime colonial a que o Brasil foi submetido (CÂNDIDO, 2004).

E, assim, essa história foi tomando outros direcionamentos. Em 25 de março de 1824 é outorgada a primeira Constituição do Brasil, chamada de Constituição Política do Império do Brasil por D. Pedro I, "que jura em nome 
Religare, ISSN: 19826605, v.15, n.1, agosto de 2018, p.48-74.

da Santíssima Trindade, observá-la e fazer que seja observada". Até então o ER continua a serviço da Igreja católica. A partir de 1889 começa um novo ideal de mudanças para a implantação do novo regime, em que a separação entre Estado e Igreja se dá pelo viés dos ideais positivistas. Holmes afirma que: “Influenciada pela Revolução francesa, a educação é atingida pela laicização do ensino, sendo responsabilidade do Estado apenas uma educação moral racional, sem qualquer interferência religiosa". (HOLMES, 2016, p. 70).

Rui Barbosa, um dos idealizadores dessa mudança, no entanto, fazia a defesa de uma escola laica sob controle do Estado. Para esse idealista, não era de competência da escola ministrar o Ensino Religioso. A Constituição da República dos Estados Unidos do Brasil, de 24 de fevereiro de 1891, é uma prova dessa mudança relacionada ao Estado Laico. Podemos observar isto através do Art. 72 nos parágrafos:

$\S 3^{\underline{o}}$ - Todos os indivíduos e confissões religiosas podem exercer pública e livremente o seu culto, associando-se para esse fim e adquirindo bens, observadas as disposições do direito comum;

$\S 6^{0}$ - Será leigo o ensino ministrado nos estabelecimentos públicos;

$\S 7^{0}$ - Nenhum culto ou igreja gozará de subvenção oficial, nem terá relações de dependência ou aliança com o Governo da União ou dos Estados;

$\S 28$ - Por motivo de crença ou de função religiosa, nenhum cidadão brasileiro poderá ser privado de seus direitos civis e políticos nem eximir-se do cumprimento de qualquer dever cívico;

$\S 29$ - Os que alegarem motivo de crença religiosa com o fim de se isentarem de qualquer ônus que as leis da República imponham aos cidadãos, e os que aceitarem condecoração ou títulos nobiliárquicos estrangeiros perderão todos os direitos políticos.

Diante disso, temos o ER fora das escolas por muitas décadas. Entretanto, com a revolução de 1930, o governo provisório de Getúlio Vargas autoriza uma série de medidas no campo educacional e, entre estas, cria o Ministério da Educação e Saúde Pública (hoje o MEC) e situa o ER nas escolas 
Religare, ISSN: 19826605, v.15, n.1, agosto de 2018, p.48-74.

públicas primárias, secundárias e normais do país, atendendo um pedido da Igreja Católica. É inicialmente admitido em caráter facultativo através do Decreto no 19.941 de 30 de abril de 1931, por conta da efetivação da Reforma Francisco Campos.

Houve constrangimento entre os "escolanovistas", que apresentaram um documento intitulado "O Manifesto dos Pioneiros da Educação Nova". Esse movimento reflete a posição do grupo contrário à inclusão da referida disciplina na escola. Os chamados "escolanovistas" posicionaram-se contra o Ensino Religioso, em nome dos princípios defendidos da laicidade, obrigatoriedade e gratuidade do ensino público.

Para eles, era uma forma de garantir e igualar o direito de escolha do cidadão de ter ou não ter religião, fundamentado na laicidade do Estado Brasileiro. Tal documento era composto de: “Um plano de reformas educacionais", que "[...] visava produzir melhorias no sistema de ensino brasileiro, sintetizado na proposição de uma escola pública, gratuita e laica e obrigatória de responsabilidade estatal" (HOLMES, 2016, p.73).

Observemos que o Presidente Getúlio Vargas instituiu a Constituição da República dos Estados Unidos do Brasil, de 16 de julho de 1934; nesse ínterim, o ER retornou às escolas, mais uma vez, à serviço de uma confessionalidade religiosa, pois o que estava em jogo novamente era o poderio da Igreja Católica, que solicitou do Presidente da República o retorno do ER. Portanto, este componente curricular foi assegurado nestes termos na Carta Magna, Art. 153 - “O Ensino Religioso será de matrícula facultativa e ministrada de acordo com os princípios da confissão religiosa do aluno, manifestada pelos pais e responsáveis, e constituirá matéria dos horários nas escolas públicas primárias, secundárias, profissionais e normais".

A partir desse período de idas e vindas, até então, esse componente curricular nunca deixou de ser confessional, sempre a critério de tal confessionalidade. Houve outras constituições com poucas mudanças sobre o 
Religare, ISSN: 19826605, v.15, n.1, agosto de 2018, p.48-74.

ER. Entretanto, somente a partir da Constituição Federal em vigor, promulgada em 1988, foi garantido, através do Art. 210, § $1^{\mathfrak{o}}$ do capítulo III da Ordem Social, o Ensino Religioso, nos seguintes termos: "O Ensino Religioso, de matrícula facultativa, constituirá disciplina dos horários normais das escolas públicas de Ensino Fundamental". Significa afirmar que esta nova proposta apresenta um marco identitário na história do Ensino Religioso.

A mudança do Ensino Religioso nos faz refletir, quanto ao seu rumo nas escolas, por se tratar de uma nova dimensão, uma nova era que caminha para a busca da sua identidade, em que um novo percurso o direciona nas escolas públicas. É necessário que a sociedade compreenda que esta nova concepção veio para desmistificar as formas preconceituosas de que o Ensino Religioso está na escola a serviço de igrejas e sua confessionalidade. Esta nova reflexão demonstra maiores entrosamentos entre toda a comunidade escolar, especialmente entre educadores e educandos, por se tratar de uma nova postura, uma nova identidade, frente à vasta diversidade cultural religiosa brasileira, sendo a escola o lugar onde se concentra grande parte de tal diversidade.

O Art. V da Constituição Brasileira de 1988 assegura: “Todos são iguais perante a lei, sem distinção de qualquer natureza, garantindo-se aos brasileiros e aos estrangeiros residentes no País a inviolabilidade do direito à vida, à liberdade, à igualdade, à segurança e à propriedade, [...]". Existe certa ignorância generalizada da sociedade a respeito das leis educacionais. Um dos aspectos que contraria essa postura é o Ensino Religioso nas escolas públicas brasileiras. Muitas pessoas não toleram nem falar deste componente curricular, porém não sabem que por trás dele existe uma base sólida de documentos, que através das leis sustentam o ER nas escolas públicas. 
Por ocasião de sua retirada da Base Nacional Curricular Comum, relembramos os acontecimentos da década de 90, quando implantaram a Lei de Diretrizes e Bases da Educação Nacional (LDBEN).

Segundo Caron (1998), em 28 de fevereiro de 1996, o Senado Federal recebe o Parecer de n⿳0 30, estabelecendo as Diretrizes e Bases da Educação Nacional. Nessas mudanças da Lei, foi criada a "Lei Darcy Ribeiro", de autoria do próprio Senador Darcy Ribeiro, apresentando mudanças, mantendo o Ensino Religioso, no Art.33, com a seguinte redação:

$\S 3^{o}$ - O Ensino Religioso, de matrícula facultativa, constitui
disciplina dos horários normais das escolas públicas de
ensino fundamental, sendo oferecido, sem ônus para os
cofres públicos, de acordo com as preferências manifestadas
pelos alunos ou por seus responsáveis, em caráter:
I-confessional, de acordo com a opção religiosa do aluno ou
do seu responsável ministrada por professores ou
orientadores religiosos preparados e credenciados pelas
respectivas igrejas ou entidades religiosas.
II- interconfessional, resultante de acordo entre as diversas
entidades religiosas que se responsabilizarão pela elaboração
do respectivo programa.
(Grifo nosso). (Senador Darcy Ribeiro)

Nesse caso como ficaria a situação das escolas? O Ensino Religioso estaria retornado às escolas, regredindo ao período da colonização, novamente? Isso implicaria em grandes dificuldades diante de tal acontecimento. Caron (1998) aponta neste texto dois pontos importantes: “um é o ER ser definido para as escolas públicas em duas modalidades, ou seja, em caráter confessional e interconfessional; o outro ponto é a expressão: “sem ônus para os cofres públicos" (CARON, 1998, p.22). Entretanto, esse componente curricular passou pela ótica de três parlamentares que apresentaram projetos de lei com a finalidade de suprir a proposta do Senador Darcy Ribeiro, foram eles: Projeto de Lei nº 2.757/97, do Deputado Nelson Marchezan; o Projeto do Deputado Maurício Requião, que tinha o no ${ }^{\circ}$ 2. 997/97, porém estes não tiveram êxito sobre forte pressão do povo. Para 
Religare, ISSN: 19826605, v.15, n.1, agosto de 2018, p.48-74.

reverter esta situação foram colhidas mais de setenta e oito mil (78.000) assinaturas de professores em todo Brasil pela mudança da lei.

FONAPER, teve total apoio dos professores de ER, e parte da sociedade brasileira, pela conquista de mudar a redação da LDB. Esse foi um acontecimento inédito na história do Ensino Religioso no Brasil, que deu uma nova conotação quanto ao seu desenvolvimento nas instituições de ensino público, respaldado não só pela Constituição Federal Brasileira, como também pela LDB (JUNQUEIRA e WAGNER, 2011).

Foi o Projeto de Lei de $n^{0} 3.043 / 97$, de autoria do Deputado Padre Roque Zimmermam, aprovado pelo Congresso Nacional, que através do Art. 33, criou a Lei substituta do ER, Lei n 9.475, de 22 de julho de 1997, dando nova redação: “O ensino religioso, de matrícula facultativa, é parte integrante da formação básica do cidadão e constitui disciplina dos horários normais das escolas públicas de ensino fundamental, assegurado o respeito à diversidade cultural religiosa do Brasil, vedadas quaisquer formas de proselitismo."

Dessa forma, além da mudança da redação da lei ${ }^{9}$, o Fonaper conseguiu, ainda nesse processo, construir tempo recorde um documento fundamental para subsidiar os professores nas escolas, ou seja, os PCNER.

\footnotetext{
${ }^{9}$ A concepção de Ensino Religioso presente na atual legislação e nos documentos produzidos pelo FONAPER é uma marca na história da educação brasileira, e especificamente para o componente curricular do ER, pois representa um salto significativo referente ao tratamento das diferentes identidades culturais e religiosas que transitam o cotidiano escolar. Observa-se nos últimos anos que as pesquisas e temáticas propostas e debatidas em eventos, tanto do FONAPER quanto de outras instituições relacionadas e comprometidas com a pesquisa e a formação de docentes em ER, estão buscando novos paradigmas que se aproximam das discussões relacionadas à Interculturalidade, aos direitos e deveres humanos, ao currículo e à formação docente sob novas perspectivas, a fim romper com os processos educacionais monoculturais, que reproduzem discriminações, preconceitos e silenciamentos no cotidiano escolar. Nessa trajetória -em busca da construção de outro paradignfa p6ra o) ER, destaca-se a ousadia do FONAPER em buscar outros olhares, perspectivas e desafios, integrando a diversidade cultural religiosa presente na sociedade e na escola brasileira. Maiores informações podem ser observadas no artigo intitulado “Concepção de Ensino Religioso no FONAPER: trajetórias de um conceito em construção" de autoria do Prof. Adecir Pozzer, publicada na obra Diversidade Religiosa e Ensino Religioso no Brasil: memórias, propostas e desafios, em 2010, em comemoração aos 15 anos do FONAPER.
} 
Religare, ISSN: 19826605, v.15, n.1, agosto de 2018, p.48-74.

Nos Parâmetros, pela primeira vez, educadores de várias tradições religiosas conseguiram elaborar propostas pedagógicas para o Ensino Religioso nas escolas, que foram apresentadas ao MEC. Nesse referencial curricular falava-se sobre a sua importância, e ao mesmo tempo era uma leitura que orientava os docentes.

[...] tendo como objeto de estudo o fenômeno religioso, sem proselitismo, mediante amplo processo de reflexão sobre os fundamentos históricos, epistemológicos e didáticos desse componente curricular, explicitando seu objeto de estudo, seus objetivos, seus eixos organizadores e seu tratamento didático. (FONAPER, 1997)

Tal documento foi entregue ao Ministério da Educação (MEC) em outubro de 1996, para reproduzir e enviar para as escolas. Todavia, o Fórum não recebeu comunicado algum a respeito desse documento, editado posteriormente pela Editora Ave-Maria, em 1997. Atualmente, está na Editora Mundo Mirim.

A Base Nacional Comum Curricular também detalha sua proposta regulamentada pela legislação, resoluções e pareceres, apresentando o ponto normativo em quatro objetivos para o ER:

a) Proporcionar a aprendizagem dos conhecimentos religiosos culturais e estéticos, a partir das manifestações religiosas percebidas na realidade dos educandos;

b) Propiciar conhecimentos sobre o direito à liberdade de consciência e de crença, no constante propósito de promoção dos direitos humanos;

c) Desenvolver competências e habilidades que contribuam para o diálogo entre perspectivas religiosas e seculares de vida, exercitando o respeito à liberdade de concepções e o pluralismo de ideias, de acordo com a Constituição Federal;

d) Contribuir para que os educandos construam seus sentidos pessoais de vida a partir de valores, princípios éticos e da cidadania (BNCC, 2017, p. 434).

A BNCC veio para consolidar e garantir uma política educacional, contribuindo na formulação do currículo nas três esferas da Educação Nacional, ou seja, Federal, Estadual e Municipal, com suas propostas e ações 
Religare, ISSN: 19826605, v.15, n.1, agosto de 2018, p.48-74.

voltadas para formação de professores, avaliação, elaboração de conteúdos educacionais para superar uma política educacional fragmentada, em prol do fortalecimento do ensino e aprendizagem. Para isso, incluiu em suas ações, no que tange ao Ensino Religioso, as seis competências específicas para o Ensino Fundamental. São elas:

1. Conhecer os aspectos estruturantes das diferentes tradições/movimentos religiosos e filosofias de vida, a partir de pressupostos científicos, filosóficos, estéticos e éticos.

2. Compreender, valorizar e respeitar as manifestações religiosas e filosofias de vida, suas experiências e saberes, em diferentes tempos, espaços e territórios.

3. Reconhecer e cuidar de si, do outro, da coletividade e da natureza, enquanto expressão de valor da vida.

4. Conviver com a diversidade de crenças, pensamentos, convicções, modos de ser e viver.

5. Analisar as relações entre as tradições religiosas e os campos da cultura, da política, da economia, da saúde, da ciência, da tecnologia e do meio ambiente.

6. Debater, problematizar e posicionar-se frente aos discursos e práticas de intolerância, discriminação e violência de cunho religioso, de modo a assegurar os direitos humanos no constante exercício da cidadania e da cultura de paz. (BNCC 2017, p.435)

Assim, observamos que este documento se apresenta em consonância com a proposta do Fórum Nacional Permanente do Ensino Religioso, através das Diretrizes Curriculares para a Educação Básica (FONAPER, 1995).

Na Paraíba, no ano de 1994, o Estado assumiu esse componente na sua grade curricular através da Secretaria Estadual da Educação (SEC), juntamente com a Arquidiocese da Paraíba. O Conselho Estadual de Educação (CEE) baixou a resolução 119/94, normatizando a disciplina, de forma confessional (HOLMES, 2016).

A partir de 1996 foi implantado em todas as escolas estaduais, de $5^{\text {a }}$ à $8^{\underline{a}}$ séries (atualmente $6^{\underline{o}}$ ao $9^{o}$ ano), envolvendo capacitação com gestores regionais e escolares da educação até a capacitação de professores de forma ecumênica com a carga horária de 120 horas. No ano de 2000, com as 
Religare, ISSN: 19826605, v.15, n.1, agosto de 2018, p.48-74.

mudanças na nova LDB (Lei de Diretrizes e Bases) pela Lei 9.475/97, houve a necessidade de se fazer uma nova capacitação dentro dos moldes do PCNER, o Curso à Distância Capacitação Docente para o Novo Milênio FONAPER (2000), fundamentado na(s) Ciência(s) da(s) Religião(ões), realizado pelo Fórum, que tinha, a cada quinze (15) dias, encontros presenciais realizados pela Coordenação do ER. Dos cem (100) educadores de ER da Rede Estadual inscritos, apenas cinquenta e seis (56) concluíram o curso (HOLMES, 2016).

Enquanto que no Município de João Pessoa, este componente curricular foi implantado no ano de 2006 em todas as escolas do Fundamental II (65). Isso teve um grande significado para todas as escolas, considerando ser o Ensino Religioso uma área de conhecimento e, por este motivo, não poderia ficar excluída dos Sistemas de Ensino. Além disso, a Secretaria de Educação e Cultura de João Pessoa (SEDEC) não poderia deixar de cumprir a Legislação Brasileira. No ano seguinte (2007) foi implantado no Fundamental I. Atualmente está em todas as escolas a partir da Educação Infantil, Ensino Fundamental e EJA, seguindo as normas da BNCC, e das Ciência(s) da(s) Religião(ões) e Legislação vigente. Para a implantação deste componente curricular foi necessário construir um documento, ou seja, um projeto, intitulado: Proposta de Implantação do Ensino Religioso na Rede Pública Municipal de Ensino de João Pessoa (Grifo nosso), que foi apresentado ao Prefeito de João Pessoa-PB. Destaca-se aqui que desde 2008 a Secretaria de Educação do Município de João Pessoa-PB, mantém um elo de parceria com a UFPB na formação continuada de professores de Ensino Religioso (HOLMES, 2016).

A análise histórica aqui realizada permite uma observação das modificações de compreensão do que é o Ensino Religioso ao longo dos anos e das mobilizações em prol da sua consolidação. Cabe ressaltar a importância do apoio de professores, alunos e diversos setores da sociedade para garantir que as disposições relacionadas a este componente curricular sejam 
Religare, ISSN: 19826605, v.15, n.1, agosto de 2018, p.48-74.

cumpridas e o Ensino Religioso seja pautado no respeito à diversidade religiosa e no estudo do fenômeno religioso.

\section{Conclusão}

Diante de tudo que foi escrito neste artigo sobre o Ensino Religioso escolar, destacamos vários marcos que nos chama atenção.

O primeiro marco: A própria história do Ensino Religioso nestes cinco séculos de percurso, sempre acompanhado da legislação e, a o mesmo tempo, a serviço de uma religião na confessionalidade da Igreja Católica;

O segundo marco: trata-se de compreender a complexidade do fenômeno religioso, que é objeto de estudo desse componente curricular, na construção do conhecimento religioso, entre docentes e discentes, nessa teia da pluralidade religiosa estabelecida na comunidade escolar, quando muitos achavam e compreendiam ser aula de religião;

O terceiro marco: Apresenta-se pela compreensão de que a diversidade cultural é a riqueza da humanidade, e como tal, a escola está permeada de valores dessa diversidade. Portanto, precisa se transformar num espaço de convivência, onde os conflitos sejam trabalhados, e não camuflados. É necessário se conhecer para conhecer o outro, e isto faz parte de uma escola cidadã mais humana, onde o educando amplia o seu conhecimento, descobrindo o sentido da convivência interpessoal, social e cultural. É através do ER que o professor desenvolve o diálogo democrático, possibilitando a formação do cidadão. Mesmo assim, esse educador depara-se com grandes desafios, como a falta de incentivo no seio do ambiente escolar e até mesmo pelos gestores das três esferas governamentais. Talvez isso ocorra por desconhecimento da Lei ou por indiferença.

O quarto marco: É o Ensino Religioso ser atualmente considerado como um componente curricular entre os demais componentes, por isso não 
Religare, ISSN: 19826605, v.15, n.1, agosto de 2018, p.48-74.

pode ser mais entendido como ensino de religião ou aula de catequese. Como podemos entender a História da Educação no Brasil sem falarmos da historicidade do Ensino Religioso? E como podemos falar da história do Ensino Religioso sem mencionar a Legislação? Isto nos faz refletir que, entre os componentes curriculares, o Ensino Religioso é o que sempre foi citado na historicidade do nosso país. Além da legislação que ampara esse componente curricular, temos ainda as Resoluções 02/1998; 04/2010 e 07/2010, e as Resoluções e Pareceres de Estados e Municípios, relacionados ao ER.

O quinto marco: São os pontos comuns apresentados no decorrer da história do ER: 1- Os Pioneiros da Educação, na sua luta pela defesa do estado laico. Entretanto, a sua saída durou alguns anos, retornando novamente na confessionalidade; 2- A Legislação, quando os legisladores, ao apresentarem a Lei de Diretrizes e Bases da Educação Nacional de n 9394/1996, Darcy Ribeiro escreveu "sem ônus para os cofres públicos": nesse ponto, essa foi uma luta que movimentou a comunidade escolar de todo Brasil e parte da sociedade pela mudança da redação da lei; 3- A sua retirada pelo MEC da terceira versão da BNCC: entregue para o julgamento do Supremo Tribunal Federal, enquanto um réu perdeu a chance de passar invicto por essa instituição tão poderosa pela defesa da diversidade religiosa, porém, dessa vez, a mobilização foi não só das escolas, como também da própria sociedade dos adeptos do Ensino Religioso Não Confessional, apresentando e enviando moções aos gestores do MEC, e sendo analisado e avaliado, retornou à base, enquanto área de conhecimento e como componente curricular reconhecidamente pela BNCC. Tudo isso está sendo acompanhado pelo FONAPER, sempre atento, para que esse processo não retroceda. Novamente, reconhecemos seu acompanhamento contínuo, do passo a passo pelo reconhecimento deste componente curricular nas Diretrizes Curriculares Nacionais (DCNs), que será votada no próximo dia 14 de dezembro de 2018. O Ensino Religioso, de acordo com a sua especificidade, não deve ser confundido com nenhuma 
Religare, ISSN: 19826605, v.15, n.1, agosto de 2018, p.48-74.

outra ciência humana, pois apresenta um grande desafio de como despertar o alunado para a percepção do Transcendente, sem fazer proselitismo. Observa-se que em cada cultura religiosa existem suas normas de valores, e essas se apresentam com ensinamentos éticos e estéticos, numa construção dialógica para a cidadania e para a cultura de paz.

\section{Referências}

ALMEIDA. Ensino Religioso: Capacitação Para Um Novo Milênio. FONAPER 2000. Caderno 03.

BERGER, Peter. O dossel sagrado: Elementos para uma teoria sociológica da religião. São Paulo: Paulus, 2004.

BRASIL. Base Nacional Comum Curricular (BNCC). MEC, 2017.

- Constituição da República Federativa do Brasil. Promulgada em 5 de outubro de 1988. Brasília: Senado Federal, Serviço Gráfico.

- Constituição da República dos Estados Unidos do Brasil de 24 de fevereiro

de 1891. Disponível em: http://www.presidencia.gov.br/legislacao/ (s.d.)

- Constituição da República dos Estados Unidos do Brasil de 16 de julho de 1934. Disponível em: http://www.presidencia.gov.br/legislacao/ (s.d.)

. BRASIL, I Constituição Política do Império do Brasil de 25 de março 1824.

A carta estabelece que a religião Católica Apostólica Romana como religião oficial do Império. Disponível em: http://www.presidencia.gov.br/legislacao/ (s.d.)

- Ministério de Educação e Cultura. Lei de Diretrizes e Bases da Educação Nacional Lei no . 9394/96 de 20 de dez. 1996. Diário Oficial da União, no 248 de 23. 12. 1996. Seção I.

- Ministério de Educação e Cultura. Nova redação do Art. 33 da Lei 9394/96. Lei nọ. 9475/97 de 22 de julho de 1997. Brasília: Diário Oficial da União, de 23 de julho de 1997, Seção I.

CÂNDIDO, Viviane Cristina. O Ensino Religioso em suas Fontes: uma contribuição para a epistemologia do ER.. Dissertação (Mestrado em Educação). Uninove, São Paulo, 2004.

- Epistemologia da controvérsia para o Ensino Religioso: aprendendo e ensinando na diferença, fundamentados no pensamento de Franz Rosenzweig. Tese (Doutorado em Ciências da Religião). Pontifícia Universidade Católica de São Paulo, 2008.

CARON, Lurdes (org.) e Equipe do GRERE. O ensino religioso na nova LDB: Histórico, exigências e documentário. Petrópolis RJ: Editora. Vozes, 1998. 
Religare, ISSN: 19826605, v.15, n.1, agosto de 2018, p.48-74.

DURKHEIM, Émile. As Formas Elementares da Vida Religiosa: (o sistema totêmico na Austrália). Tradução: Joaquim Pereira Neto SP: 2 edição. Ed. Paulus, 1989.

ELIADE, Mircea. O Sagrado e o Profano: a essência das religiões. Tradução: Rogério Fernandes. São Paulo: 5 Tiragem, Martins Fontes, 2001.

. Tratado da História das Religiões. Tradução: Fernando Tomaz e Natália Nunes. São Paulo: Martins Fontes, 1993.

FIGUEREDO, Anísia de Paulo. Palestra para professores de ER no XII SEFOPER. Faculdade Salesiana Dom Bosco, Manaus/AM, 13 a 15 de setembro de 2012.

FONAPER. Parâmetros Curriculares Nacionais do Ensino Religioso. São Paulo: Mundo Mirim, 2009.

. "Ensino Religioso Capacitação Para Um Novo Milênio". O Fenômeno

Religioso. Caderno 04, 2000, p. 13

FREIRE, Paulo. Pedagogia do Oprimido. 46 ed.São Paulo, SP: Paz e Terra S/A, 2007 a. 213 p.

HERVIEU-LÉGER, Danièle. O peregrino e o convertido: a religião em movimento. Petrópolis: Vozes, 2008.

HOLMES. Maria José Torres. Ensino Religioso: esperanças e desafios. Reflexões da práxis do cotidiano escolar. Florianópolis: Saberes em Dialogo, 2016.

. Maria José Torres. Ensino Religioso: problemas e desafios. Dissertação (Mestrado em Ciências das Religiões). UFPB, 2010.

JUNQUEIRA, Sérgio. BRANDENBURG, Laude. KLEIN, Remi (Org.). Compêndio do Ensino Religioso. São Leopoldo/Petrópolis: Sinodal/Vozes, 2017. Sérgio. GABIREL, René. KLUCK, Claudia. RODRIGUES, Edile. Socialização do saber e produção científica do ensino religioso. Porto Alegre, Editora Fi, 2017

Sérgio e WAGNER, Raul. Uma breve história do FONAPER 1995-2010.

In: O Ensino Religioso no Brasil. Curitiba: CHAMPAGNAT, 2011.

STEEL, Edson. Ensino Religioso: Ensino Fundamental II. São Paulo-SP. Global Editora, 2009.

OLIVEIRA, Lilian Blanck de et al. Ensino Religioso: no Ensino Fundamental. São Paulo, SP: Cortez, 2007. (Coleção docência em formação. Série Ensino Fundamental).

ORO, Ivo Pedro. O Fenômeno Religioso: como entender. São Paulo: Paulinas, 2013 - (Coleção temas de religião).

PINHEIRO, Danielle Ventura de Lima; PINHEIRO, Gilmário Kassandro Xavier. Valores universais em sala de aula: possibilidades pedagógicas para o Ensino Religioso. In: Eunice Simões Gomes; Sérgio Rogério Junqueira. (Org.). Ensino Religioso: Religião e Cultura. 1 ed. João Pessoa: UFPB, 2016, v. 1, p. 182-193. POZZER, Adecir. Concepção de ensino religioso no FONAPER: Trajetórias de um conceito em construção. POZZER, Adecir; et al. (Orgs.) Diversidade Religiosa e 
Religare, ISSN: 19826605, v.15, n.1, agosto de 2018, p.48-74.

Ensino Religioso no Brasil: memórias, propostas e desafios. São Leopoldo: Nova Harmonia, 2010, p. 83-101. 